\title{
A Systematic Review of Iranian Experiences in Seismo-Nephrology
}

\author{
Behrooz Hashemi, ${ }^{1}$ Saeed Safari, ${ }^{1}$ Mostafa Hosseini, ${ }^{2}$ Mahmoud Yousefifard, ${ }^{3}$ Elham Erfani, ${ }^{1}$ Alireza \\ Baratloo, ${ }^{1}$ Farhad Rahmati, ${ }^{1}$ Maryam Motamedi, ${ }^{1}$ Mohammad Mehdi Forouzanfar, ${ }^{1}$ and Iraj Najafi ${ }^{4,5,}$ \\ ${ }^{1}$ Department of Emergency Medicine, Shahid Beheshti University of Medical Sciences, Tehran, IR Iran \\ ${ }^{2}$ Department of Epidemiology and Biostatistics, School of Public Health, Tehran University of Medical Sciences, Tehran, IR Iran \\ ${ }^{3}$ Department of Physiology, School of Medicine, Tehran University of Medical Sciences, Tehran, IR Iran \\ ${ }^{4}$ Shafa Continuous Ambulatory Peritoneal Dialysis Research Center, Dialysis and Transplant Patients Association (DATPA), Tehran, IR Iran \\ ${ }^{5}$ Department of Internal Medicine, Dr. Shariati Hospital, Tehran University of Medical Sciences, Tehran, IR Iran \\ "Corresponding author: Iraj Najafi, Department of Internal Medicine, Dr. Shariati Hospital, Tehran University of Medical Sciences, Tehran, IR Iran. Tel/Fax: +98-2122721155, \\ E-mail: najafi63800@yahoo.com
}

Received 2015 March 30; Revised 2015 June 18; Accepted 2015 July 15.

\begin{abstract}
Context: Crush syndrome and its potentially life-threatening complications, such as acute kidney injury (AKI), are one of the most important medical problems of disaster victims. However, today, many unanswered questions abound about the potential risk factors of crush syndrome, predictive factors of AKI, proper amount of prophylactic hydration therapy, type of fluid, time of continuing fluid, intravenous versus oral hydration, etc. Therefore, this study was designed to review the findings on Iranian nephrologist experiences in diagnosis and management of traumatic rhabdomyolysis following the last two strong earthquakes of Bam (2003) and Manjil-Rudbar (1990).

Evidence Acquisition: The study was conducted according to the MOOSE reporting guideline. A literature review was conducted on the nephrologic aspects of earthquakes in Iran. Relevant articles were identified through a comprehensive search of online databases until 2014. The search was limited to articles studying the Iranian population published in English and Persian languages. The validated combination of MeSH terms and key words was used. In addition, a manual search was run among the references of all articles that met the entrance criteria and previous reviews. Only cohort, case-control, and cross-sectional studies were enrolled. Two reviewers independently reviewed the eligible studies, and another reviewer contributed in case of a disagreement. Basic information from each study was evaluated from the aspects of purpose and design, year of publication, methodology, main population, and source of data. The quality of the included studies was assessed using methods guide for effectiveness and comparative effectiveness reviews. Two reviewers independently rated each paper as "good", "fair", or "poor".

Results: A total of 1256 non-duplicate articles were identified, but only 35 potentially relevant papers were screened. Finally, 21 articles were found eligible and studied in details. In addition, one unpublished report was included. In the quality assessment, two articles had poor quality, and thus only 20 were finally included in the systematic review. No publication bias (coefficient = -2.28 ; $95 \%$ Confidence interval: $-6.17-1.78 ; \mathrm{P}=0.26$ ) was observed among the included studies.

Conclusions: A few eligible articles on seismo-nephrology were found in Iran, and a limited number of current articles had poor or fair quality. As expected, the chaotic situation after mass disasters and the lack of documentation led to the loss of much important data on the diagnosis and management of victims. Lessons learned from the current researches can be used as a valuable guide for future studies.
\end{abstract}

Keywords: Rhabdomyolysis, Crush Syndrome, Acute Kidney Injury, Earthquake, Disaster Medicine

\section{Context}

Crush syndrome and its potentially life-threatening complications, such as acute kidney injury (AKI), are one of the most important medical problems of disaster victims. In this regard, AKI is recognized as the most serious, although preventable, complication that should be paid more attention $(1,2)$. The early and urgent management of AKI is essential to reduce the morbidity and the mortality associated with crush syndrome. The estimated proportion of AKI patients who require hemodialysis varies widely from $0 \%$ to $75 \%$ in different studies (3,
4). The chaotic situation after mass disasters changes the routine practice condition in the management of patients and mandates the use of specific protocol in such a situation. Several studies have been performed on the diagnosis and treatment of crush-induced AKI after mass disasters. However, today, many unanswered questions abound about the potential risk factors of crush syndrome, predictive factors of AKI, proper amount of prophylactic hydration therapy, type of fluid, time of continuing fluid, intravenous versus oral hydration, etc. For example, although administration of up to $12 \mathrm{~L}$ of prophylactic fluid can be ap-

Copyright ( $)$ 2016, Kashan University of Medical Sciences.. This is an open-access article distributed under the terms of the Creative Commons Attribution-NonCommercial 4.0 International License (http://creativecommons.org/licenses/by-nc/4.0/) which permits copy and redistribute the material just in noncommercial usages, provided the original work is properly cited. 
plicable for non-disaster situations, the lack of sufficient medical and non-medical resources will not make disaster situations any easier. In the past centuries, many destructive earthquakes occurred in Iran, but only a few studies have been conducted on disaster management, particularly seismo-nephrology. However, after two recent major destructive earthquakes in Iran, Bam (southeast, 6.6 on the Richter scale) and Manjil Rudbar (north, 7.6 on the Richter scale), several studies were performed on the different medical aspects of disaster victims. Accordingly, this study was designed to review the finding of Iranian nephrologist experiences on the diagnosis and management of traumatic rhabdomyolysis following the last two big earthquakes (Bam in 2003 and Manjil-Rudbar in 1990). The key points of this study include the epidemiologic, therapeutic, predictive, and preventive strategies.

\section{Evidence Acquisition}

\subsection{Search Strategy}

The study was conducted according to the MOOSE statement, which provides a detailed guideline of the preferred reporting style for systematic reviews and metaanalyses of observational studies in epidemiology (5). A literature review was conducted on the nephrologic aspects of earthquakes in Iran. Relevant articles were identified through a comprehensive search of online databases (Medline, Embase, Scopus, Cochrane, Google Scholar, CINAHL, SUMSearch, SID, Magiran, and Iran Medex) until 2014. The search was limited to articles studying the Iranian population published in English and Persian languages. The following validated combinations of MeSH terms and key words were used: crush syndrome, rhabdomyolysis, injuries, earthquake, disasters, humans, Iran, acute kidney injury, myoglobinuria, renal insufficiency, kidney failure, acute kidney tubular necrosis, renal replacement therapy, acute kidney injury/therapy, crush syndrome/complications, muscular diseases/etiology, nephrology, and treatment outcome.

In addition, a manual search was run on the reference lists of all articles that met the entrance criteria and previous reviews to find additional studies. The wide search was set to include the maximum number of relevant papers. The search was completed by assessing the bibliographies of identified relevant studies. Attempts were made to contact the authors of all studies that met the entrance criteria and to request for their unpublished data and abstracts. The search flow is summarized in Figure 1.

\subsection{Data Extraction and Management}

Two reviewers (EE and SS) independently reviewed all potentially eligible studies that could meet the selection criteria. Another reviewer (MY) would make the final decision in case of a disagreement. We included all cohort, case-control, and cross-sectional studies of crush injury patients with rhabdomyolysis from all age groups. Any type of duplicate research, research protocols, commentaries, editorials, letters, and books was excluded from this review. Basic information from each study was evaluated from the aspects of purpose and design, year of publication, methodology, main population, and source of data.

In the standard Table 1 (6-24), data of the included papers were summarized by first author, publication year, study design, region of the earthquake, number of patients, numbers and sources of control (for case-control studies) or study size at baseline (for cohort studies), main findings, and statistical adjustments.

We contacted the authors if they did not report the number of patients and outcomes. If the information was reported as graphs, we extracted the information from the graphs as recommended by Sistrom et al. (25). The funnel plot was used to evaluate publication bias based on Egger et al.'s methods (26).

\subsection{Quality Assessment}

The quality of the included studies was assessed using the methods guide for effectiveness and comparative effectiveness reviews developed by the agency for healthcare research and quality (AHRO) (27). Two reviewers were independently assigned to each paper to rate it as "good", "fair", or "poor". Quality assessment was conducted on the basis of the criteria relevant to observational studies accounting for study design and presence of bias (selection, performance, recording, or reporting bias). Poor-quality studies were defined as those that had a high risk of bias. Studies with a moderate risk of bias that did not affect the results were categorized as fair quality, and those with a minimal risk of bias were considered good quality. Inter-rater reliability was acceptably high (82\%). Disagreements were discussed with a third reviewer(MY) and settled by consensus.

\section{Results}

\subsection{Selection of Studies}

A total of 1256 non-duplicate articles were identified, and 35 potentially relevant papers were screened. Finally, 21 were found eligible and studied in detail (Figure 1). In addition, one unpublished report was included. In the quality assessment, two articles had poor quality, and thus the remaining 20 (6-24) were included in the systematic review. No publication bias (coefficient $=-2.28$; $95 \%$ confidence interval: $-6.17-1.78 ; \mathrm{P}=0.26$ ) was observed among the included studies. Only studies with sufficient quality 


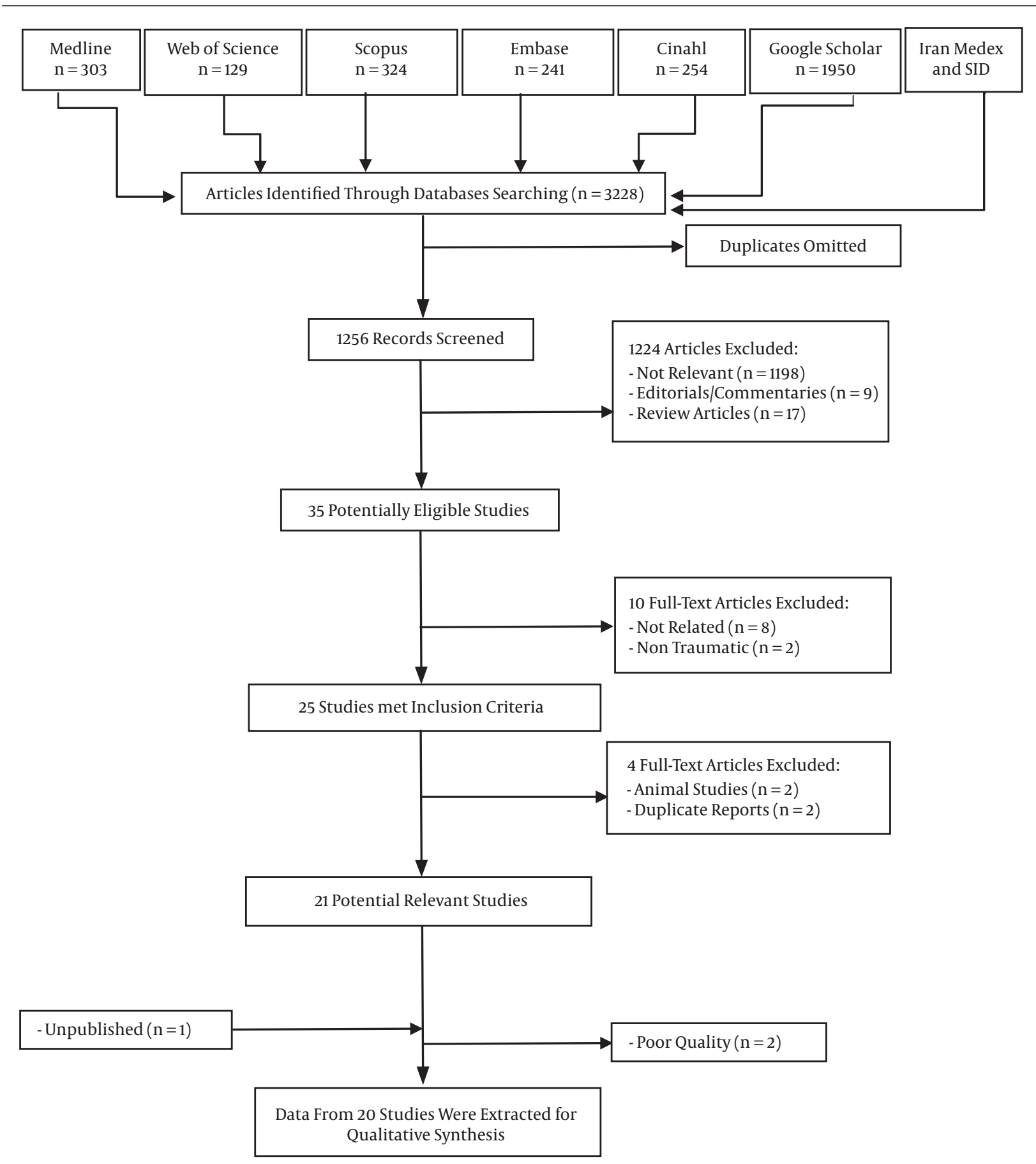

Figure 1. Flow Chart of the Study

were included in the research. To protect against publication bias, the studies were searched using the method of Egger to reject the bias. The repetition of this analysis using Begg's method showed similar results $(\mathrm{P}=0.27)$.

\subsection{Epidemiology}

Based on results of the systematic review, 19 (two papers were removed because of poor quality) relevant articles in the field of seismo-nephrology in the Iranian population have been published in Persian or English lan- 
guage. These studies were conducted on the two strong earthquakes that occurred in Iran, namely, Bam (2003) and Manjil-Rudbar (1990). During the Bam earthquake, around 142000 residents were affected and more than 25514 (90\%) died at the scene of the disaster. About 30000 were injured, and nearly 12000 patients were referred to hospitals across the country (15 hospitals and 8 cities) (17). About 7000 out of the 12000 patients referred to the medical centers were hospitalized (15). Based on comprehensive study on the Bam earthquake by Hatamizadeh et al. the data of 2962 admitted victims (40\% female), with an average age of $28.4 \pm$ 14.2 years (ranging from 1 - 90), were collected (12). The data of about 800 patients who were referred to Shiraz city were not enrolled because of the poor contribution of this city to the study of Najafi et al. (2). During the Manjil-Rudbar earthquake, about 43390 persons were injured, 13888 died, and 33615 were hospitalized (28).

\subsection{Time Under the Rubble}

Different reports were conducted on the average time for being under the rubble. The incidence of AKI was directly related to first-time medical aid. In Hatamizadeh et al. the average of TUR was reported to be $6.3 \pm 3.1$ hour for AKI patients and $2.4 \pm 1.6$ for others (12). Patients with crush injury were entrapped 2.2 hours longer than noncrushed subjects (17). Seyrafian et al. revealed a significant longer TUR in AKI (8.41 hours) and dialyzed cases (11.72 hours) (8). The TUR in patients who underwent hemodialysis was 1 hour longer than that in other AKI patients in Bidari et al.'s study (5.7 \pm 1 vs. $4.75 \pm 4.6$ hours) (9). A significant correlation was found between TUR and the serum creatinine kinase (CK) level (16). In Tahmasebi's study on 210 patients, the mean TUR was 1.9 hours, and a significant association was found between the incidence of compartment syndrome and TUR(10). The mean times spent under the rubble in pediatric victims of the Bam earthquake were $2.2 \pm 2.5$ hours and $0.5 \pm 0.5$ hours in crush and non-crush injury patients, respectively (19). No statistically significant difference was found between crush syndrome and crush injury pediatric patients in terms of TUR (19).

\subsection{Crush Injury, Crush Syndrome, and Crush-Induced Acute} Kidney Injury

Different reports were conducted on the incidence of crush-induced AKI following an earthquake in Iran (1.1\% to 6.7\%). During the Bam earthquake 611 patients obtained crush injury (20.6\%), 200 cases (6.7\% of all patients and $32.7 \%$ of crush injury patients) developed crush syndrome, and 128 (21.3\%) developed AKI (64\% of crush syndrome patients) (17). About $82.1 \%$ of AKI victims underwent dialysis (22). AKI occurred in 8 out of 15 (53\%) pediatric patients who had crush injury. No significant difference was observed in the mean age between patients with AKI and other patients. The mean duration of patients' hospitalization in the AKI and non-AKI groups was statistically significant ( $\mathrm{P}$ $<0.001$ ) (8). Oliguric patients needed more dialysis than the non-dialysis group (nearly fourfold) and had high mortality (nearly threefold) (8). Fasciotomy (38.9\% vs. $1.9 \%$ ), amputation (6.1\% vs. $0.5 \%$ ), and death (12.7\% vs. $1.9 \%$ ) were more frequent in AKI pediatric patients (19) than in other patients. Ahmadinejad's study consisted of 112 pediatric patients who were referred to Tehran University of Medical Sciences hospitals, and five patients developed AKI (4.5\%, with an age range of 13-18 years) (7). In Sagheb et al.'s study on 801 victims of the Bam earthquake referred to hospitals in Shiraz city, 20 (2.5\%) victims developed AKI with a mean age of $36.2 \pm 14.8$ years ( 15 males) and mean duration of $14.5 \pm 9.6$ days. In total, 79 dialysis sessions were performed in 15 patients (mean 5.2, $3.3 \pm 1$ session per patients) (16). In Tahmasebi's study on 210 patients, 14 (6.7\%) subjects had AKI (10). In Hamzeh et al.'s study on hospitalized patients during the Bam earthquake in hospitals in Kerman province, 54 patients (17 females and 37 males) were detected with AKI, with a mean age of 31 years old (range of 16 - 45 years) (13). In Bidari's unpublished study (congress), 10.6\% of the 1052 patients hospitalized after the Bam earthquake, with a mean age of 28.4 years, were diagnosed with AKI with CK level $>3 \mathrm{mg} / \mathrm{dL}$. About $71.2 \%$ of all AKI cases underwent hemodialysis (9). According to Nadjafi et al.'s report on the Manjil Rudbar earthquake (6), AKI patients were more severely injured, and they had a significantly higher incidence of multiple traumas, peripheral nerve damage, and elevated plasma concentrations of muscle enzymes (22). The incidence of AKI and the need for dialysis were mostly affected by CPK, TUR, volume of fluid received, and delayed onset of fluid therapy. A significant association was found between the severity of the trauma (TUR and CPK) and the delayed onset of fluid therapy with the occurrence of AKI and need for dialysis $(\mathrm{P}<0.001)$.

\subsection{Electrolyte Imbalance}

Hamzeh et al. detected 20.4\% hypocalcaemia and 70.4\% hyperuricemia in AKI patients within the first week of admission (13). Hatamizadeh's study reported hyperkalemia in 68 victims of the Bam earthquake (7.6\%; $n=$ 896) at the time of hospitalization (12). According to Nadjafi et al. the level of serum muscle enzymes, potassium, phosphate, and abnormal urinalysis significantly elevated among AKI patients (6). Despite the expectation of hyperphosphatemia among earthquake victims, a significantly higher incidence of hypophosphatemia was found among Bam earthquake victims $(\mathrm{P}=0.02)$ according to the unpub- 
lished results of Mooraki et al.'s study presented in the $9^{\text {th }}$ annual Iranian congress of nephrology.

\subsection{Therapeutic Intervention}

Intravenous fluids can help prevent renal ischemia by increasing the kidney perfusion and force diuresis because of the high rate of morbidity and mortality among rescued victims $(3,29,30)$. Different experiences suggested 3 - 12 L of fluids to prevent AKI in the first 24 hours after an earthquake $(28,29,31-33)$. To prevent rhabdomyolysis in severely rhabdomyolized patients, Najafi et al. recommended more than $6 \mathrm{~L}$ of prophylactic fluid and 3 - 6 L for less traumatized patients. As the fluid volume increases, the need for dialysis significantly decreases (22). Sanadgol et al. found that prompt fluid therapy could prevent both AKI and dialysis. The mean volume of delivered fluid in pediatric patients was $3.6 \pm 0.99 \mathrm{~L}$ in the AKI group and $4.8 \pm 0.74$ in the non-AKI group. The mean values of intravenous fluid in the crush and non-crush injury patients were $217 \pm 58$ and $112 \pm 45$ ( $\mathrm{mL} / \mathrm{kg} /$ day), respectively. This study considered the delivered to expected ratio (DL/EX) as a good predictor of adequate fluid therapy in pediatrics. They estimated the DL/EX ratio of $>4.8$ as a good point to prevent AKI in the pediatric population (19). In Sagheb et al. patients who received a proper amount of fluid had significantly shorter duration of AKI (7.1 days vs. 9.4) and a lesser need for dialysis ( 1 session vs. 6 sessions) (16). Tolouian et al. introduced the oral alkalinizing solution (OAS) as a feasible alternative to intravenous hydration to prevent crush-induced AKI in the context of mass disasters where intravenous hydration is not possible. This study showed that a dose of 10 $\mathrm{ml} / \mathrm{kg} /$ hour of OAS could be the correct amount to induce alkaline diuresis within the first 12 hours after crush injury. According to the results of this study, all cases tolerated the OAS without adverse events and had active diuresis ( $>200$ $\mathrm{mL} /$ hour) after an average of $3.0 \pm 0.7$ hours. Their urine became alkaline $(\mathrm{pH}>7.0)$ within an average of $3.25 \pm 0.8$ hours (11).

\subsection{Fasciotomy}

Another therapy that is mandatory to restore perfusion to affected tissues and that prevents irreversible damage and subsequent disability in the early treatment of crushed victims is fasciotomy. Fasciotomy was more frequent in patients with AKI (38.9\% vs. $1.9 \%)$ than in those without (12). Theoretically, fasciotomy can complicate the nephrologic problems of patients by increasing muscle damage and the subsequent release of nephrotoxic muscle enzyme. In Safari et al. fasciotomy was conducted in 70 of 200 patients with crush-induced AKI (35.0\%). The procedure did not increase the rates of disseminated intravascular coagulation, sepsis, adult respiratory distress syndrome, amputation, and dialysis session (23). In Beygi et al. the two-year follow-up of patients showed that fasciotomy was not only a safe method but also essential for limb salvaging (14).

\subsection{Mortality Rate}

The overall mortality rate of earthquake victims in Iran was reported to be $1.9 \%-8.3 \%$, which was higher among AKI, dialyzed, and fasciotomized patients in different studies. The study of Hatamizadeh et al. showed the overall mortality rate of $1.9 \%$ and the AKI mortality rate of $12.7 \%$ for victims of the Bam earthquake (12). Nadjafi et al. reported $14 \%$ overall mortality rate and $40 \%$ for dialyzed patients following the Manjil-Rudbar earthquake (6). In Seyrafian's study, the mortality rate of 818 Bam earthquake victims referred to Isfahan was $1.4 \%$ (62.1\% female). Among these victims, 7.09\% suffered crush syndrome (58/818) and 62.06\% suffered AKI (36/58) (8). The total mortality rate was $2.6 \%$ and $2 \%$ in Sagheb et al. (16) and Amini et al. (20), respectively. Hamzeh reported a mortality rate of $8.3 \%$ and $11.5 \%$ in fasciotomized and non-fasciotomized patients, respectively (13).

Mooraki et al. presented a mortality rate of $2.7 \%$ for hypophosphatemic and $10.5 \%$ for hyperphosphatemic patients.

\subsection{Prediction of At-Risk Patients}

The lack of sufficient resources and the large number of injured patients mandate the planning for the proper use of facilities. In this way, the early detection of and the focus on high-risk patients to determine crush-induced AKI are strategic and can solve problems. Najafi et al. recommended two algorithms that enable the attending medical personnel to predict the development of AKI on the first days of a disaster based on simple biochemical parameters that could easily be made available even in a disaster scene (15). They also suggested that patients with serum CK greater than $15000 \mathrm{U} / \mathrm{L}$ should be considered for urgent prophylactic fluid therapy, and those with CK levels $<10000 \mathrm{U} / \mathrm{L}$ were less likely to develop AKI. Although CK is the gold standard in the prediction of AKI, the dipstick urine test is an early screening tool for detecting victims prone to AKI. Amini et al. showed the use of the urine dipstick test (UDT) to detect myoglobinuria in high-risk victims as a rapid and applicable predictive test. No significant difference was seen in the sensitivity, specificity, and accuracy of dipstick urine and serum CPK tests for identifying patients at risk of AKI (20). In another study, AlaviMoghaddam et al. evaluated the use of UDT for screening rhabdomyolysis and AKI due to crush injury. UDT was also considered and recommended as an early screening tool for AKI detection (24). 


\section{Conclusions}

Iran lies in a complex geologic zone and is prone to earthquakes because of several major fault lines running across the country (34). Based on historical references, Tehran, the largest city and capital of Iran, has been destroyed by catastrophic earthquakes for at least six times now, with the oldest one occurring in $4^{\text {th }}$ century BC (35). An earthquake that may one day strike Tehran can kill hundreds of thousands people and destroy most of the buildings. Experts believe that a quake as strong as the one that flattened Bam can lead to higher mortality rate in Tehran. Other countries with a similar geographic pattern have the same condition. Therefore, being prepared for a probable situation is very important. In this regard, lessons learned from previous studies may be helpful. For this purpose, the most important findings from Iranian studies in the field of seismo-nephrology are summarized as follows:

A significant correlation exists between TUR on one side and the incidence of crush syndrome, compartment syndrome, and formation of AKI on the other side. This finding is in contrast to some of the present reports in this field (36). It can be explained by the specific local structure of buildings in the studied earthquakes. When a disaster occurs in frameless mud brick buildings, the entrapped part of the body compresses under the direct pressure of the debris. However, in concrete or steel-framed buildings, triangular spaces formed by a whole part of a roof or a wall can save victims from direct pressure.

The incidence of AKI (1.1\% - 6.7\%) in these two studied earthquakes was considerably lower than that in previous studies, such as in the Kobe earthquake in Japan in 1995 (31) and the Marmara earthquake in Turkey (36). The same trend was observed in the mortality rate of Iran's earthquakes compared with that of the Tangshan (37), Kobe (31), Marmara (36), and Mexico City earthquakes (38). These differences may be a reflection of delayed relief, weakness of triage and transportation, and other limitations that increase the mortality of victims at the scene. Therefore, the transported patients were those with low severity of trauma and its complications and consequently low rate of AKI and mortality.

Regarding prophylactic treatment, the Bam earthquake experience showed that the most important point for receiving better outcomes is the selection of at-risk patients and the concentration of limited resources to such patients. Based on these practices, the optimal amount of fluid for the production of acceptable urine output was 6 $\mathrm{L}$ in 24 hours for adult victims. Moreover, the delivered to expected ratio $>4.8$ was identified as a good predictor of adequate fluid therapy in pediatric patients. The findings show that in contrast to other reports, early fasciotomy in patients with compartment syndrome could save the limb without any additional complication, such as sepsis, adult respiratory distress syndrome, and higher incidence of AKI $(39,40)$.

The main finding of all the mentioned studies was to find ways to predict at-risk patients. For the first time, the Bam earthquake research team presented a number of predictive measures, such as the rule of thumb, AKI formula, and urine dipstick. Validation of these tools with further study in the future can correct their weak points and help find at-risk patients during the most preventable times before the establishment of a complete picture of AKI.

\subsection{Strength and Weakness Points}

This present systematic review has important strength points. We conducted an extensive literature search, including different databases, and used a comprehensive analytical approach that involves more studies. Our rigorous methods were based on the guidelines for conducting and reporting systematic reviews.

This study also has some limitations. First, all the original studies were observational and therefore were limited to this type of study in which causal relationships could not be established. Generally, as limited studies have been performed on disaster medicine, we have to use the findings of a few and, in some cases, poor-quality studies. Second, data gathering in most of the included studies in the present study was cross-sectional and based on patient records. This issue can affect the study findings because data registration in the patients' files was acceptable only at $65 \%$ (21). Conversely, most of the studies were crosssectional, and thus the outcome of the earthquake victims who suffered from AKI was not comparable with those of other cases. Third, the lack of meta-analysis was due to the overlapping of some studies with each other. For example, the 200 patients of Sagheb et al. (16) overlapped with those of Sanadgol et al. (19).

Only a few eligible articles on seismo-nephrology have been conducted in Iran, and a limited number of current articles had poor or fair quality. As expected, the chaotic situation after a mass disaster and the lack of documentation led to the loss of important data on the diagnosis and management of victims. However, lessons learned from the present research can be used as a valuable guide for future studies.

\section{Acknowledgments}

The authors would like to thank all the people who cooperated in this study. 


\section{Footnote}

Authors' Contribution: All authors passed the four criteria for authorship contribution based on the recommendations of the international committee of medical journal editors.

\section{References}

1. Rostami Z, Pezeshki ML. Role of NGAL for the early detection of acute kidney injury. Nephro-Urol Mo. 2010;2(03):387-9.

2. Najafi A, Ahmadi A, Fallahian F. Acute kidney injury following crush injury and earthquakes. Shiraz E Med Journal. 2011;12(2):66-76.

3. Sever MS, Erek E, Vanholder R, Ozener C, Yavuz M, Kayacan SM, et al. Lessons learned from the Marmara disaster: Time period under the rubble. Crit Care Med. 2002;30(11):2443-9. doi: 10.1097/01.CCM.0000034681.60341.07. [PubMed: 12441752].

4. Wood D, Rosedale K. Crush syndrome in the rural setting. Emerg Med J. 2011;28(9):817. doi:10.1136/emj.2010.104208. [PubMed: 21653202].

5. Stroup DF, Berlin JA, Morton SC, Olkin I, Williamson GD, Rennie D, et al. Meta-analysis of observational studies in epidemiology: a proposal for reporting. Meta-analysis Of Observational Studies in Epidemiology (MOOSE) group. JAMA. 2000;283(15):2008-12. [PubMed: 10789670].

6. Nadjafi I, Atef MR, Broumand B, Rastegar A. Suggested guidelines for treatment of acute renal failure in earthquake victims. Ren Fail. 1997;19(5):655-64. [PubMed: 9380884].

7. Ahmadinejad Z, Ziaee V, Bagherian H, Zarinfar N, Mohajerani SA. Demographic and clinical findings of pediatric trauma patients of Bam earthquake in 2003. Iran J Pediatr. 2004;14(2):94-100.

8. Seyrafian S, Taheri S, Bayat A, Atapour A, Mortazavi M, Kadkhodaie F. Acute renal failure Bam earthquake victims [Persian]. J Isfahan Med Sch. 2004;22(72):1-6.

9. Bidari A, Hosseinnezhad A, Zare M, Hatamabadi H, Farahmand S, Arhami A, et al. Prevalence of Acute Renal Failure in Hospital Patients Injured in the Bam Earthquake. Prehosp Disaster Med. 2005;20(S2):S145.

10. Tahmasebi MN, Kiani K, Mazlouman SJ, Taheri A, Kamrani RS, Panjavi $\mathrm{B}$, et al. Musculoskeletal injuries associated with earthquake. A report of injuries of Iran's December 26, 2003 Bam earthquake casualties managed in tertiary referral centers. Injury. 2005;36(1):27-32. doi: 10.1016/j.injury.2004.06.021. [PubMed:15589909].

11. Tolouian R, Wild D, Lashkari MH, Najafi I. Oral alkalinizing solution as a potential prophylaxis against myoglobinuric acute renal failure: preliminary data from healthy volunteers. Nephrol Dial Transplant. 2005;20(6):1228-31. doi: 10.1093/ndt/gfh779. [PubMed: 15784638].

12. Hatamizadeh P, Najafi I, Vanholder R, Rashid-Farokhi F, Sanadgol H, Seyrafian S, et al. Epidemiologic aspects of the Bam earthquake in Iran: the nephrologic perspective. Am J Kidney Dis. 2006;47(3):428-38. doi: 10.1053/j.ajkd.2005.11.019. [PubMed:16490621].

13. Hamzeh E. Demographic Study of Acute Renal Failure Victims of Bam Earthquake, 2003. Kerman, Iran: Kerman University of Medical Sciences; 2007.

14. Beygi AA, Nourian SE, Goharian V, Ghoreyshi M, Taheri H, Sehat S. Fasciatomy for crush injury; the results of two years fallow up in bam earthquake. Iran J Surg. 2007;15(1):114-20.

15. Najafi I, Van Biesen W, Sharifi A, Hoseini M, Rashid Farokhi F, Sanadgol H, et al. Early detection of patients at high risk for acute kidney injury during disasters: development of a scoring system based on the Bam earthquake experience. J Nephrol. 2008;21(5):776-82. [PubMed: 18949734].

16. Sagheb MM, Sharifian M, Roozbeh J, Moini M, Gholami K, Sadeghi H. Effect of fluid therapy on prevention of acute renal failure in Bam earthquake crush victims. Ren Fail. 2008;30(9):831-5. doi: 10.1080/08860220802353785. [PubMed: 18925519].

17. Hosseini M, Safari S, Amini M, Farokhi Farin R, Mooraki A, Sanadgol $\mathrm{H}$, et al. Wide spectrum of traumatic rhabdomyolysis in earthquake victims. Acta Med Iran. 2009;47(6):459-64.

18. Najafi I, Safari S, Sharifi A, Sanadgol H, Hosseini M, Rashid-Farokhi F, et al. Practical strategies to reduce morbidity and mortality of natural catastrophes: a retrospective study based on Bam earthquake experience. Arch Iran Med. 2009;12(4):347-52. [PubMed: 19566350].

19. Sanadgol H, Najafi I, Rajabi Vahid M, Hosseini M, Ghafari A. Fluid therapy in pediatric victims of the $2003 \mathrm{bam}$, Iran earthquake. Prehosp Disaster Med. 2009;24(5):448-52. [PubMed: 20066650].

20. Amini M, Sharifi A, Najafi I, Eghtesadi Araghi P, Rasouli MR. Role of dipstick in detection of haeme pigment due to rhabdomyolysis in victims of Bam earthquake. Eastern Mediterra health journal. 2010;16(9):977-81.

21. Dehghani-Firoozabadi MH, Abedinzadeh M, Moslemi MK. Genitourinary system trauma after 2003 Bam earthquake in Kerman, Iran. Ther and clin risk manage. 2011;7:49.

22. Najafi I, Safari S, Hosseini M, Sanadgol H, Sharifi A, Farokhi Farin R, et al. Prophylactic fluid therapy in crushed victims of Bam earthquake. Am jemerg med. 2011;29(7):738-42. doi: 10.1016/j.ajem.2010.02.018. [PubMed: 20825890].

23. Safari S, Najafi I, Hosseini M, Sanadgol H, Sharifi A, Alavi Moghadam M, et al. Outcomes of fasciotomy in patients with crush-induced acute kidney injury after Bam earthquake. Iran J Kidney Dis. 2011;5(1):25-8. [PubMed: 21189430]

24. Alavi-Moghaddam M, Safari S, Najafi I, Hosseini M. Accuracy of urine dipstick in the detection of patients at risk for crush-induced rhabdomyolysis and acute kidney injury. Eur J Emerg Med. 2012;19(5):32932. doi: 10.1097/MEJ.ob013e32834dd2ef. [PubMed: 22082877].

25. Sistrom CL, Mergo PJ. A simple method for obtaining original data from published graphs and plots. AJR Am J Roentgenol. 2000;174(5):1241-4. doi:10.2214/ajr.174.5.1741241. [PubMed:10789769].

26. Egger M, Davey Smith G, Schneider M, Minder C. Bias in meta-analysis detected by a simple, graphical test. BMJ. 1997;315(7109):629-34. [PubMed: 9310563].

27. Agency for Healthcare Research and Quality. Methods Guide for Effectiveness and Comparative Effectiveness Reviews. United State: Rockville; 2013. Available at: http://effectivehealthcare.ahrq.gov/ index.cfm/search-for-guides-reviews-and-reports/?productid= $318 \&$ pageaction $=$ displayproduct.

28. Atef MR, Nadjatfi I, Boroumand B, Rastegar A. Acute renal failure in earthquake victims in Iran: epidemiology and management. QJ Med. 1994;87(1):35-40. [PubMed: 8140215].

29. Gunal AI, Celiker H, Dogukan A, Ozalp G, Kirciman E, Simsekli H, et al. Early and vigorous fluid resuscitation prevents acute renal failure in the crush victims of catastrophic earthquakes. J Am Soc Nephrol. 2004;15(7):1862-7. [PubMed:15213274].

30. Ron D, Taitelman U, Michaelson M, Bar-Joseph G, Bursztein S, Better OS. Prevention of acute renal failure in traumatic rhabdomyolysis. Arch Intern Med. 1984;144(2):277-80. [PubMed: 6696564].

31. Oda Y, Shindoh M, Yukioka H, Nishi S, Fujimori M, Asada A. Crush syndrome sustained in the 1995 Kobe, Japan, earthquake; treatment and outcome. Ann Emerg Med. 1997;30(4):507-12. [PubMed: 9326866].

32. Vanholder R, Sever MS, Erek E, Lameire N. Acute renal failure related to the crush syndrome: towards an era of seismo-nephrology? Nephrol Dial Transplant. 2000;15(10):1517-21. [PubMed: 11007816].

33. Shimazu T, Yoshioka T, Nakata Y, Ishikawa K, Mizushima Y, Morimoto $\mathrm{F}$, et al. Fluid resuscitation and systemic complications in crush syndrome: 14 Hanshin-Awaji earthquake patients. J Trauma. 1997;42(4):641-6. [PubMed: 9137251].

34. Talebian M, Jackson J. A reappraisal of earthquake focal mechanisms and active shortening in the Zagros mountains of Iran. Geophys J Int. 2004;156(3):506-26. doi: 10.1111/j.1365-246X.2004.02092.x. 
35. Ghodrati Amiri G, Motamed R, Rabet Es-Haghi H. Seismic hazard assessment of metropolitan Tehran, Iran. J Earthquake Eng. 2003;7(3):347-72. doi:10.1080/13632460309350453.

36. Sever MS, Erek E, Vanholder R, Akoglu E, Yavuz M, Ergin H, et al. The Marmara earthquake: epidemiological analysis of the victims with nephrological problems. Kidney Int. 2001;60(3):1114-23. doi: 10.1046/j.1523-1755.2001.0600031114.x. [PubMed: 11532107].

37. Sheng ZY. Medical support in the Tangshan earthquake: a review of the management of mass casualties and certain major injuries. $J$ Trauma. 1987;27(10):1130-5. [PubMed: 3312621].
38. Villazon-Sahagun A. Mexico City earthquake: medical response. Prehosp Disaster Med. 1986;2(1-4):15-20.

39. Matsuoka T, Yoshioka T, Tanaka H, Ninomiya N, Oda J, Sugimoto H, et al. Long-term physical outcome of patients who suffered crush syndrome after the 1995 Hanshin-Awaji earthquake: prognostic indicators in retrospect.J Trauma. 2002;52(1):33-9. [PubMed:11791049].

40. Sever MS, Erek E, Vanholder R, Akoglu E, Yavuz M, Ergin H, et al Clinical findings in the renal victims of a catastrophic disaster: the Marmara earthquake. Nephrol Dial Transplant. 2002;17(11):1942-9. [PubMed: 12401851]. 
Table 1. Summary of Included Papers

\begin{tabular}{|c|c|c|c|c|c|c|c|c|c|c|}
\hline \multirow{2}{*}{$\begin{array}{l}\text { Study (year), } \\
\text { Location of } \\
\text { Earthquake }\end{array}$} & \multirow[t]{2}{*}{ Reference } & \multirow[t]{2}{*}{ No. of Patients } & \multirow{2}{*}{$\begin{array}{c}\text { Age, } \\
\text { Mean } \\
\text { (range), } \\
\quad \mathbf{y}\end{array}$} & \multirow{2}{*}{$\begin{array}{l}\text { Gender } \\
\text { (Male\%) }\end{array}$} & \multirow{2}{*}{$\begin{array}{l}\text { Outcome } \\
\text { Measure }\end{array}$} & \multicolumn{3}{|c|}{ Results } & \multirow[t]{2}{*}{ Weaknesses } & \multirow[t]{2}{*}{ Quality } \\
\hline & & & & & & Dialysis & $\begin{array}{c}\text { Mortality } \\
\text { Rate }\end{array}$ & Comment & & \\
\hline $\begin{array}{c}\text { Nadjafi et al. } \\
\text { (1997); } \\
\text { Manjil-Roudbar }\end{array}$ & (6) & $\begin{array}{l}495 \text { injured } \\
\text { patients/30 AKI }\end{array}$ & $\mathrm{NA}$ & $\mathrm{NA}$ & $\begin{array}{l}\text { AKI requiring } \\
\text { dialysis and } \\
\text { mortality rate }\end{array}$ & 100 & $\begin{array}{l}14 \% \text { na- } \\
\text { tionwide } \\
40 \% \text { in } \\
\text { AKI cases }\end{array}$ & $\begin{array}{l}\text { On admission, patients with } \\
\text { ARF were more severely } \\
\text { injured and had } \\
\text { significantly higher } \\
\text { incidence of multiple } \\
\text { trauma than those without } \\
\text { ARF; peripheral nerve injury; } \\
\text { elevated muscle enzymes, } \\
\text { potassium, and phosphorus; } \\
\text { and abnormal urinalysis. }\end{array}$ & $\begin{array}{l}\text { Small sample size; study was } \\
\text { performed in three teaching } \\
\text { hospitals in Tehran (capital } \\
\text { of Iran) }\end{array}$ & Fair \\
\hline $\begin{array}{l}\text { Ahmadinejad et } \\
\text { al. (2004); Bam }\end{array}$ & (7) & $\begin{array}{l}112 \text { pediatric } \\
\text { patients/5 AKI } \\
\text { cases }\end{array}$ & $\begin{array}{l}13.06(13- \\
18)\end{array}$ & 45.54 & $\begin{array}{l}\text { AKI incidence in } \\
\text { pediatric patients }\end{array}$ & $\mathrm{NA}$ & $\mathrm{NA}$ & $\begin{array}{l}\text { Eighty-two percent of all } \\
\text { patients were transported to } \\
\text { hospitals within the first } \\
\text { three days after the } \\
\text { earthquake. Thirty percent } \\
\text { of all patients suffered from } \\
\text { infectious disease, and the } \\
\text { most common infectious } \\
\text { disease was urinary tract } \\
\text { infection. The good } \\
\text { management of our patients } \\
\text { caused a low rate of acute } \\
\text { renal failure and any clinical } \\
\text { findings of tetanus. The high } \\
\text { rate of limb injuries requires } \\
\text { appropriate management in } \\
\text { the future. }\end{array}$ & $\begin{array}{l}\text { Missing data were not } \\
\text { implicated. Data gathering } \\
\text { was based on medical } \\
\text { records. }\end{array}$ & Fair \\
\hline $\begin{array}{l}\text { Seyrafian et al. } \\
\text { (2004); Bam }\end{array}$ & (8) & $\begin{array}{l}818 \text { victims } / 36 \text { case } \\
\text { of AKI }\end{array}$ & $\begin{array}{l}40.4(12- \\
65)\end{array}$ & 45.3 & $\begin{array}{l}\text { Mortality rate of } \\
\text { AKI patients }\end{array}$ & 44.4 & $\begin{array}{l}22.2 \text { in } \\
\text { AKI } \\
\text { patients }\end{array}$ & $\begin{array}{l}\text { The immediate diagnosis } \\
\text { and treatment of patients } \\
\text { can improve the results due } \\
\text { to the intent, serious } \\
\text { complications, and high } \\
\text { mortality rate of crush } \\
\text { syndrome. In this study, the } \\
\text { rate of overall mortality was } \\
\text { lower than that in prior } \\
\text { studies. The need for dialysis } \\
\text { was also less. }\end{array}$ & $\begin{array}{l}\text { Low sample size; data } \\
\text { gathering was based on } \\
\text { medical records. }\end{array}$ & Fair \\
\hline $\begin{array}{l}\text { Bidari et al. } \\
\text { (2005); Bam }\end{array}$ & (9) & $\begin{array}{l}1056 \\
\text { hospitalized/112 } \\
\text { cases of AKI }\end{array}$ & $\begin{array}{l}28.4(1 . \\
90)\end{array}$ & 65.5 & $\begin{array}{l}\text { Incidence of AKI } \\
\text { and need for } \\
\text { dialysis }\end{array}$ & 71.2 & $\mathrm{NA}$ & $\begin{array}{l}\text { A considerable number of } \\
\text { earthquake victims } \\
\text { developed AKI in the first } \\
\text { week following the event. } \\
\text { Most of them underwent } \\
\text { hemodialysis. }\end{array}$ & $\begin{array}{l}\text { Data gathering was based on } \\
\text { medical records. }\end{array}$ & Good \\
\hline $\begin{array}{l}\text { Tahmasebi et al. } \\
\text { (2005); Bam }\end{array}$ & (10) & $\begin{array}{l}210 \text { injured } \\
\text { patients/6 } 6 \text { ARF }\end{array}$ & $\begin{array}{l}30.2(7- \\
70)\end{array}$ & 42.4 & $\begin{array}{l}\text { ARF requiring } \\
\text { dialysis }\end{array}$ & $\begin{array}{l}\text { all ARF } \\
\text { cases }\end{array}$ & $\mathrm{NA}$ & $\begin{array}{l}\text { Some patients had } \\
\text { compartment syndrome } \\
(8.6 \%) \text {, and 16.7\% ( }(35) \text { had } \\
\text { major soft tissue injury. The } \\
\text { incidence of renal failure } \\
\text { increased with the increase } \\
\text { in time from rescue to first } \\
\text { medical aid but was } \\
\text { relatively independent of } \\
\text { time being under rubble. }\end{array}$ & Low ARF cases & Fair \\
\hline $\begin{array}{l}\text { Tolouian et al. } \\
\text { (2005); Volunteer } \\
\text { Ir anian Army }\end{array}$ & (11) & $\begin{array}{l}12 \text { healthy } \\
\text { volunteers s }\end{array}$ & $\begin{array}{l}19.4(18- \\
20)\end{array}$ & 100 & $\begin{array}{l}\text { Effect of oral } \\
\text { alkalinizing } \\
\text { solution on the } \\
\text { prevention of ARF }\end{array}$ & $\mathrm{NA}$ & $\mathrm{NA}$ & $\begin{array}{c}\text { All subjects tolerated the } \\
\text { OAS without adverse events } \\
\text { and had active diuresis (> } \\
200 \mathrm{~mL} / \mathrm{h}) \text { after an average } \\
\text { of } 3.0 \pm 0.7 \mathrm{~h} \text {. Their urine } \\
\text { became alkaline (pH > }>\text {.0) } \\
\text { within an average of } 3.25 \pm \\
0.8 \mathrm{~h} \text {. No significant } \\
\text { electrolyte abnormalities } \\
\text { were found. }\end{array}$ & $\begin{array}{l}\text { Low sample size; the study } \\
\text { was not a cohort } \\
\text { representative of ARF } \\
\text { victims. }\end{array}$ & Fair \\
\hline
\end{tabular}




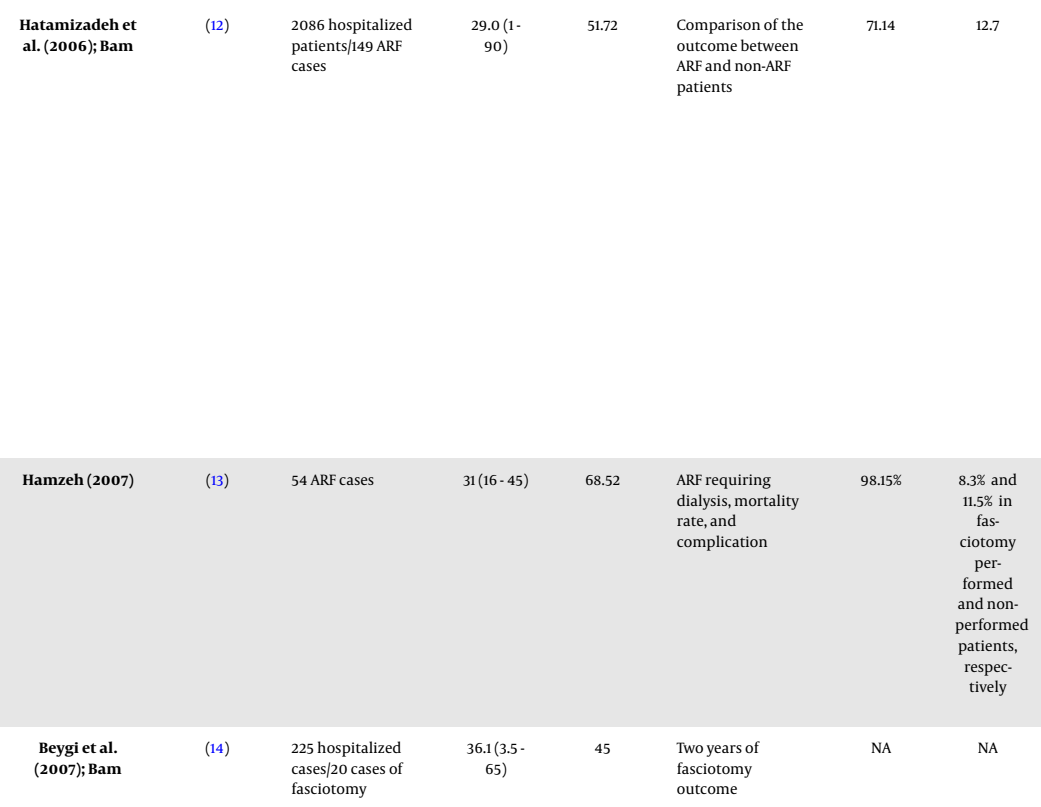

Sepsis, DIC, ARDS, hyperkalemia, fasciotomy, amputation, and death were higher in AFR patients than in non-AFR patients. Patien with acute renal falure were entrapped longer and hospitalized later and for longer periods. Medical complications, surgical procedures, and mortality rate were greater in the latter group. Early hospitalization with appropriate
appralization appropriate
multidisciplinary care are
critical to prevent acute renal failure and its subsequent mortality in earthquake conditions.

$51.9 \%$ of patients h
oliguria, $94.4 \%$

hypocalcemia, $20.4 \%$ hypocalcaemia, and $70.4 \%$ hyperuricemia. The mean creatinine phosphokinase vel was greater than 400 lactate dehydrogenate 20 30 , and aminotransferases 5 -10 fold of the normal range. in 24 patients (44.4\%).

Fasciotomy is not only a safe procedure but also Fascioto limb salvages. Fasciotomy can also functioning of limbs. For best results, physical therapy and prosthesis usage are necessary for patients. Even if fasciotom cannot preserve limb unction, it must be done to salvage the limb.

A rule of thumb to detect victims without risk for AKI below $2 \mathrm{mg} / \mathrm{dL}$, LDH below $2000 \mathrm{IU}$, and serum uric acid below $6 \mathrm{mg} / \mathrm{dL}$, the probability of developing AKI would be virtually zero. Likewise, a value for the equation ( $0.45 \mathrm{CPK}+2.5 \mathrm{LDH}$ $+2700 \mathrm{~K}+2000$ uric acid 14000) 10000 of $>2.0$ is appropriate to distinguish victims at risk from tho
not at risk for AKI.

. time spent under the rubble and the peak serum CK level can be used to estimate morbidity, and early standard treatment may decrease renal morbidity.

\begin{tabular}{|c|c|c|c|c|c|c|c|c|c|c|}
\hline $\begin{array}{l}\text { Hosseini et al. } \\
\text { (2009); Bam }\end{array}$ & (17) & $\begin{array}{l}2962 \\
\text { hospitalized/3611 } \\
\text { cases of moderate- } \\
\text { to-severe } \\
\text { rhabdomyolysis }\end{array}$ & $\begin{array}{l}28.4(1- \\
90)\end{array}$ & 60 & $\begin{array}{l}\text { Assessment of the } \\
\text { stepwise } \\
\text { management } \\
\text { protocol in Bam } \\
\text { victims }\end{array}$ & $\mathrm{NA}$ & $\mathrm{NA}$ & $\begin{array}{l}\text { A total of } 611 \text { patients were } \\
\text { affected with crush injury } \\
\text { (20\%). These patients were } \\
\text { entrapped } 2.2 \mathrm{~h} \text { longer than } \\
\text { the others }(\mathrm{P}<0.001) \text {. Mean } \\
\text { intravenous intake in first } \\
\text { five days was } 3.6 \mathrm{~L}(\mathrm{SD} 2.6) \text { for } \\
\text { these patients compared } \\
\text { with } 2.5 \mathrm{~L}(\mathrm{SD} 1.4) \text { for the } \\
\text { others }(\mathrm{P}<0.001) \text {. A total of } \\
200 \text { cases showed the } \\
\text { complete features of crush } \\
\text { syndrome. }\end{array}$ & Large missing data & Fair \\
\hline $\begin{array}{l}\text { Najafi et al. } \\
\text { (2009); Bam }\end{array}$ & (18) & $\begin{array}{l}4552 \text { medical } \\
\text { records }\end{array}$ & $\mathrm{NA}$ & NA & $\begin{array}{l}\text { Assessment of the } \\
\text { medical records of } \\
\text { Bam earthquake } \\
\text { victims }\end{array}$ & $\mathrm{NA}$ & $\mathrm{NA}$ & $\begin{array}{l}\text { Only } 65 \%(2984 / 4552) \text { had } \\
\text { acceptable medical records. } \\
\text { A considerable number (23\%) } \\
\text { of victims received their first } \\
\text { intravenous infusion within } \\
12 \mathrm{~h} \text { after the quake (earliest: } \\
10 \text { min, latest: } 96 \mathrm{~h} \text { ). The } \\
\text { mean volume of intravenous } \\
\text { fluid infused in the first } 24 \mathrm{~h} \\
\text { was } 1800 \mathrm{~mL} \text { (min: } 0 \text {, max: } \\
6000 \mathrm{~mL}) \text {. Among the } \\
\text { patients with documented } \\
\text { death status, } 1.7 \% \text { (48/2701) } \\
\text { died in hospitals. }\end{array}$ & $\begin{array}{l}\text { Data gathering method and } \\
\text { the number of removed data } \\
\text { were not reported }\end{array}$ & Fair \\
\hline
\end{tabular}

Retrospective manner of Good study could have affected data gathering. Missing data was partially high.

Selection bias; small sample $\quad$ Fair

Low sample size; blindness of not performed
Fair

\section{All biochemical parameters were available in all patients
Follow-up period was short medical record

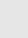

Data gathering was based on Good
Sagheb et al. 801 injured
patients/20 AR $70)$ 70) 


\begin{tabular}{|c|c|c|c|c|c|c|c|c|c|c|}
\hline $\begin{array}{l}\text { Sanadgol et al. } \\
\text { (2009); Bam }\end{array}$ & (19) & $\begin{array}{l}15 \text { cases of crush } \\
\text { injury/16 } \\
\text { non-crush injury } \\
\text { cases }\end{array}$ & $8.2(0-14)$ & 33 & $\begin{array}{l}\text { ARF requiring } \\
\text { dialysis }\end{array}$ & 53 & $\mathrm{NA}$ & $\begin{array}{l}\text { Acute renal failure did not } \\
\text { develop in any of the } \\
\text { children with non-CI, but it } \\
\text { occurred in } 8 \text { of the } 15 \\
\text { patients }(53 \%) \text { who had } \\
\text { sustained CI. Among } \\
\text { children with crush injuries, } \\
\text { DL/EX ratio of }>4.8 \text { was } \\
\text { sufficient for the prevention } \\
\text { of ARF. The delivered } \\
\text { intravenous fluid of }>3.6 \\
\text { can reduce the need for } \\
\text { dialysis. }\end{array}$ & $\begin{array}{l}\text { Low sample size; possible } \\
\text { selection bias }\end{array}$ & Fair \\
\hline $\begin{array}{l}\text { Amini et al } \\
\text { (2010); Bam }\end{array}$ & (20) & $\begin{array}{l}79 \text { victims } / 8 \text { cases } \\
\text { of ARF }\end{array}$ & $\begin{array}{l}28.4(0- \\
90)\end{array}$ & 68 & $\begin{array}{l}\text { The dipstick urine } \\
\text { test was used in } \\
\text { the identification } \\
\text { of ARF. }\end{array}$ & 50 & $25 \%$ & $\begin{array}{l}\text { The dipstick urine test is a } \\
\text { highly sensitive and an easy } \\
\text { screening tool to identify } \\
\text { patients who are at risk of } \\
\text { developing ARF due to } \\
\text { rhabdomyolysis, and it may } \\
\text { have a role in the early } \\
\text { detection of patients at the } \\
\text { site of an earthquake. The } \\
\text { results did not reveal } \\
\text { significant differences } \\
\text { between the dipstick urine } \\
\text { test and the serum CPK in } \\
\text { identifying patients who } \\
\text { were at risk of ARF. }\end{array}$ & $\begin{array}{l}\text { Low sample size; single } \\
\text { center was studied. }\end{array}$ & Fair \\
\hline $\begin{array}{l}\text { Dehghani- } \\
\text { Firoozabadi et al } \\
\text { (2011); Bam }\end{array}$ & (21) & $\begin{array}{l}256 \text { cases of } \\
\text { earthquake } \\
\text { victims } 28 \text { cases } \\
\text { with urologic } \\
\text { damage }\end{array}$ & $\begin{array}{l}47(18- \\
65)\end{array}$ & 78.5 & $\begin{array}{l}\text { Earthquake- } \\
\text { related } \\
\text { genitourinary } \\
\text { system trauma }\end{array}$ & NA & $\mathrm{NA}$ & $\begin{array}{l}21 \text { cases ( } 75.5 \%), \\
\text { vesicovaginal fistula in four } \\
\text { cases (14\%), kidney rupture } \\
\text { in two cases (7\%), and } \\
\text { bladder neck disruption } \\
\text { accompanied with total } \\
\text { right ureteral disruption } \\
\text { and vesicovaginal fistula in a } \\
\text { female patient (3.5\%) }\end{array}$ & $\begin{array}{l}\text { Whether standard } \\
\text { assessments of urinary tract } \\
\text { trauma were performed for } \\
\text { all patients was not defined. }\end{array}$ & Good \\
\hline $\begin{array}{l}\text { Najafi et al. (2011) } \\
\text { Bam }\end{array}$ & (22) & $\begin{array}{l}504 \\
\text { rhabdomyolysis } \\
\text { and } 134 \text { AKI cases }\end{array}$ & $\begin{array}{l}28.4(1- \\
90)\end{array}$ & 68.1 & $\begin{array}{l}\text { AKl-requiring } \\
\text { dialysis }\end{array}$ & 82.1 & $\mathrm{NA}$ & $\begin{array}{l}\text { The analysis showed the } \\
\text { preventive role of more than } \\
6 \text { Lof fluid per day in severe } \\
\text { rhabdomyolysis and } 3 \mathrm{~L} \text { per } \\
\text { day in moderate ones in the } \\
\text { development of AKI and } \\
\text { dialysis. }\end{array}$ & $\begin{array}{l}\text { The retrospective manner of } \\
\text { the study may affect data } \\
\text { gathering. }\end{array}$ & Good \\
\hline \multirow[t]{2}{*}{$\begin{array}{l}\text { Safari et al. (2011) } \\
\text { Bam }\end{array}$} & (23) & 200 AKI cases & $\begin{array}{l}27.4(10- \\
65)\end{array}$ & 49 & $\begin{array}{l}\text { Outcomes of } \\
\text { fasciotomy }\end{array}$ & NA & $\mathrm{NA}$ & $\begin{array}{l}\text { Fasciotomy was performed } \\
\text { for } 70 \text { of } 200 \text { patients with } \\
\text { crush-induced AKI ( } 35.0 \%) \text {. } \\
\text { The mean CPK level of } 24433 \\
\pm 3969 \text { IU/L confirmed } \\
\text { severe rhabdomyolysis in } \\
\text { this subset of patients. }\end{array}$ & $\begin{array}{l}\text { Did not compare fasciotomy } \\
\text { with the conservative } \\
\text { method }\end{array}$ & Good \\
\hline & & & & & & & & $\begin{array}{l}\text { This study showed that the } \\
\text { outcomes of patients with } \\
\text { crush-induced AKI were not } \\
\text { affected by fasciotomy } \\
\text { during the Bam earthquake. }\end{array}$ & & \\
\hline $\begin{array}{c}\text { Alavi- } \\
\text { Moghaddam et } \\
\text { al. (2012); Bam }\end{array}$ & (24) & $\begin{array}{l}2962 \\
\text { hospitalized/354 } \\
\text { cases of } \\
\text { rhabdomyolysis } \\
\text { and AKI }\end{array}$ & $\begin{array}{l}28.4(1- \\
90)\end{array}$ & 60 & $\begin{array}{l}\text { Urine dipstick test } \\
\text { was used for } \\
\text { detecting } \\
\text { rhabdomyolysis } \\
\text { and AKI }\end{array}$ & 41.8 & $\mathrm{NA}$ & $\begin{array}{l}\text { Blood-positive UDTs } \\
\text { (without considering the } \\
\text { RBC count) had a sensitivity } \\
\text { of } 92.5(95 \% \text { CI: } 79.6-98.4 \text { ) } \\
\text { for a CPK cut-off of } 15000 \\
\text { (IU/L) for detecting } \\
\text { rhabdomyolysis and acute } \\
\text { kidney injury. }\end{array}$ & $\begin{array}{l}\text { Large data missing; this gap } \\
\text { and the therapeutic efforts } \\
\text { in this time interval may } \\
\text { have influenced the results. }\end{array}$ & Fair \\
\hline $\begin{array}{c}\text { Mooraki et al. } \\
\text { (Unpublished) }\end{array}$ & (Unpublished) & $\begin{array}{l}1372 \text { crush-injured } \\
\text { victims of Bam }\end{array}$ & $\begin{array}{l}27.4(15- \\
35)\end{array}$ & 52 & $\begin{array}{l}\text { Evaluation of } \\
\text { phosphate ion } \\
\text { levels in patients } \\
\text { with } \\
\text { rhabdomyolysis }\end{array}$ & $\mathrm{NA}$ & $\begin{array}{l}2.7 \% \text { in } \\
\text { hy- } \\
\text { pophos- } \\
\text { phatemic } \\
\text { and } 10.5 \% \\
\text { in hyper- } \\
\text { phos- } \\
\text { phatemic } \\
\text { patients }\end{array}$ & $\begin{array}{l}\text { Despite the expectation of } \\
\text { hyperphosphatemia in } \\
\text { earthquake victims, this } \\
\text { study found a significantly } \\
\text { higher incidence of } \\
\text { hypophosphatemia among } \\
\text { Bam earthquake victims. }\end{array}$ & Large data missing & Fair \\
\hline
\end{tabular}

